\title{
PROFESSIONAL PRACTICE SCHOOLS AS A FORM OF SCHOOL-UNIVERSITY PARTNERSHIP IN TEACHER EDUCATION: TOWARDS A SOCIAL JUSTICE AGENDA
}

\section{Maureen Robinson}

Stellenbosch University

Email: mrobinson@sun.ac.za

\section{ABSTRACT}

Twenty years into democracy, South Africa is still struggling to improve the quality of its education system. The identification of schools that can work closely with universities to mentor student teachers has been suggested as one way in which teacher education can contribute to an improved education system. The article outlines research that was conducted to establish the conditions for the establishment of Professional Practice schools, seen as schools that, regardless of resource level, would offer excellent support to student teachers on Teaching Practice. Drawing on activity theory as well as Fraser's (2008) three dimensional theory of justice, the paper explores the challenges and possibilities of such school-university partnerships as a form of social justice in South Africa. Vision, agency, shared expertise, material conditions and institutional capacity are argued to be key factors of a system-wide approach to enhancing teacher education in the country.

Keywords: Teacher education; teaching practice; school-university partnerships

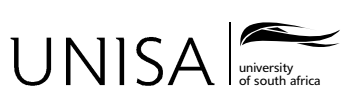

Education as Change

Volume 20 | Number 2 | 2016 | pp. 11-26

www.educationaschange.co.za

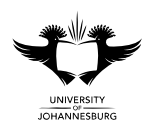

DOI: http://dx.doi.org/10.17159/1947-9417/2016/496 Print ISSN 1682-3206 | Online 1947-9417

(C) 2016 The Author(s) 


\section{INTRODUCTION}

One of the most important arenas for social reconstruction in a post-apartheid era continues to be that of education. Against a challenging social environment, a myriad of policies and initiatives have been aimed at addressing the disparities in educational achievement across different sectors of society and at improving the quality of education (see Sayed, Kanjee \& Nkomo 2013).

In the arena of initial teacher education, the most significant policy revisions over the last twenty years have been the incorporation of colleges of education into higher education, the provision of recruitment bursaries for academically strong candidates in designated subjects, and the introduction of a new national framework for teacher education qualifications.

After a number of years with a significant drop in recruits into teacher education, as a consequence of a poor image of teaching, higher university entry requirements compared to colleges of education, and the more urban and centrally located geography of university sites, student numbers have started to rise again, with new teacher graduates from South Africa's public universities increasing from about 6000 new teachers in 2008 to about 16000 in 2013 (DHET 2015a). The emphasis in policy has thus shifted from increasing enrolments to ensuring quality and substance in teacher education.

A recent intervention for improving teacher education has been to explore the notion of Professional Practice schools, or schools that are able to offer excellent learning opportunities for student teachers during their Teaching Practice period, or practicum. This paper describes the background to this proposed intervention, and outlines the findings of research into the viability of establishing such schools. It links the notion of Professional Practice schools to categories from activity theory and frameworks for social justice and outlines the constraints and possibilities for such an intervention to contribute to improved teacher education across the system.

\section{INITIAL TEACHER EDUCATION QUALIFICATIONS}

A short description of the South African teacher education policy is needed to locate the research described here within the qualifications framework for becoming a teacher. Teacher education qualifications are governed by the Revised Policy on the Minimum Requirements for Teacher Education Qualifications (DHET 2015b). Two qualifications enable new recruits to enter the teaching profession: a four year Bachelor of Education (B Ed), or a one year Postgraduate Certificate in Education (PGCE), which caps an undergraduate Bachelor's degree. Both these qualifications can be offered only by universities or recognised private providers and, unlike in a number of other countries, no alternative or 'fast-track' routes into teaching exist.

The teacher education qualifications policy emphasises various types of knowledge that underpin teachers' practice and encapsulates these in the notion 
of integrated and applied knowledge. The framework resists the notion of a purely skills-based approach, and foregrounds knowledge, reflection, connection, synthesis and research. Different types of knowledge for teaching are identified, namely disciplinary, pedagogical, practical, fundamental and situational learning. A minimum set of eleven competences are outlined, for example, 'newly qualified teachers must have sound subject knowledge' and 'newly qualified teachers must be able to manage classrooms effectively across diverse contexts in order to ensure a conducive learning environment' (DHET 2015b). As long as they adhere to a shared basic structure and certain quality criteria, universities are free to design their teacher education curriculum as they so wish.

The involvement of schools in the school-based component of initial teacher education is loosely defined by these programme requirements. Both the B Ed and PGCE include a compulsory school-based component of about eight to twelve weeks per year that must be structured, supervised and integrated into the learning programme and formally assessed (DHET 2015b, 13). Teacher education programmes are funded via student fees and state subsidy, with much contestation from faculties of education around the fact that teacher education is in the lowest funding level of the state subsidy system. Schools do not receive any funding for accommodating and mentoring student teachers. No policy prescriptions in the form of contracts or training exist for how schools and universities collaborate; the general way of working resembles the description of the pre-1983 period in the United Kingdom (Browne \& Reid 2012) where student teachers are attached to a qualified teacher for a period of time, the university determines the detail of the student's professional development and assessment, and teachers are seen as informal guides rather than equal partners.

\section{THE TEACHER DEVELOPMENT SUMMIT}

Despite the many new policies and strategies, and the hard work of many committed individuals and organisations, the legacy of poor schooling remains an intractable challenge. In July 2009, a Teacher Development Summit was held in South Africa, with the primary goal being that of addressing the challenges being experienced in teacher education and development in the country. In a sector characterised by a very active and often contested civil society, the summit was noteworthy for bringing together the many stakeholders from across the teacher development sector in South Africa. This included the ministries of education responsible for school and higher education, the teacher unions, the professional council for teachers, the labour bargaining council, the skills, development and training agency, and the Education Deans' Forum. However, even with the symbolic targeting of 'a harmonising of voices' (Samuel 2014, 616), the challenges of policy implementation still remained.

The summit resulted in a declaration that called for the development of a new, strengthened and integrated national plan for teacher development in South 
Africa. This national plan was encompassed in the Integrated Strategic Planning Framework for Teacher Education and Development in South Africa 2011-2025 and identified and described specific outputs and activities that in combination were intended to improve the quality of teacher education and development, in order to improve teaching and learning in South Africa.

One of the activities in the plan referred to the role of universities in strengthening the school-based component of teacher education. This was specified as strengthening the teaching practice/school experience component of teacher education programmes through the development of Teaching Schools (TSs) and Professional Practice Schools (PPSs) (DBE \& DHET 2011, 18).

\section{PROFESSIONAL PRACTICE SCHOOLS}

Professional Practice Schools (PPSs) were defined as the type of schools, regardless of resource level, at which student teachers would receive quality support during their normal period of school-based training. They were thus not seen as 'extraordinary' schools; the idea rather being that PPSs would be drawn from the usual schools where students were placed for Teaching Practice. The idea was that student teachers would be able to engage in learning-in-practice in such schools, with proper mentoring. Over time, the intention was that sufficient PPSs would be identified to offer good support to most if not all initial teacher education students. PPSs would also be utilised as hubs for the development of professional learning communities.

Teaching Schools, in contrast to Professional Practice schools, were defined as 'teaching laboratories'. These were seen as individual schools, located close to a teacher education delivery site, where student teachers could observe best practices, participate in teaching experiences and potentially link research and teaching (Gravett, Petersen \& Petker 2014; Henning, Petker \& Petersen 2015; Gravett \& Ramsaroop 2015).

The description of the Professional Practice schools in the Integrated Plan was not elaborated beyond a few sentences, but there are resemblances with international initiatives. One thinks of Professional Development Schools in the USA (DarlingHammond 2014), urban teacher residencies, also in the USA (Klein, Taylor, Onore, Strom, \& Abrams 2013), internship schemes in the United Kingdom (Browne \& Reid 2012), programmes in Australia (Broadbent \& Brady 2013), school-university partnerships in Hong Kong (Tsui, Edwards \& Lopez-Real 2009), and similar initiatives in many other countries (Mattson, Vidar Eilertsen \& Rorrison 2011). In a sense then, one could argue that this initiative was nothing new, the significance being rather in the call to harness collective resources across the system to improve the contribution of teacher education to the quality of education in the country.

Much debate has taken place internationally about the purpose and format of school involvement in teacher education (Browne \& Reid 2012), with some 
expressing caution about an unproblematic assumption that school involvement leads to better teacher education. Ellis (2010), for example, argues that experience in schools has the potential to lead to the reproduction of routines and the development of 'bureaucratic virtues' like compliance. In the USA, Zeichner, Payne \& Brayko (2015) have highlighted challenges associated with sustaining inter-institutional initiatives to build democracy, including budget constraints, heavy work demands, accountability pressures, and the labour-intensive nature of building inter-institutional collaborations.

Considering the depth and scope of these international debates, it is important to note that the recommendation to establish Professional Practice schools was not accompanied by any prior research; rather it was couched as a political declaration emerging from a process of national stakeholder deliberation. While the stakeholder agreement is in itself significant, it is clear that any such initiative, if it was to be more than a pronouncement, would have to be accompanied by a clear conceptualisation of purpose and an analysis of conditions for implementation.

To its credit, then, the Department of Higher Education and Training, the government ministry responsible for teacher education, commissioned a research report into the conditions for establishing PPSs, in order better to understand what it might take to make such schools a reality. The findings of this research provide the 'case' to explore the issue of system choices for planning teacher education for social justice, the interest of this paper.

\section{RESEARCH INTO THE ESTABLISHMENT OF PROFESSIONAL PRACTICE SCHOOLS IN SOUTH AFRICA}

The research reported on here (Robinson 2015) focused on the following questions:

- What lessons can be learned from international initiatives similar to the PPS?

- What organisational factors at schools and universities, as well as at education department level, best support quality work-integrated learning across a variety of contexts?

- What challenges do schools and universities experience in respect of these curriculum and organisational factors, and how are these addressed?

- What existing resource, policy or legislative factors at school, university and education department level support or constrain the functions of PPSs?

Purposive sampling, where sites are chosen with a view to gathering the most useful findings, was used to identify the research participants. Sampling was done on the basis of potential for success, since the intention was to explore examples of possibility. 
Written and verbal invitations were sent to all universities in the country, inviting them to participate in the research. Each of the universities that responded positively was then asked to identify two schools that they thought showed promise as a potential PPS. In this way, nine universities and eighteen schools, based in five provinces, became part of the research. Both schools and universities were located across the social and economic spectrum. Data was gathered mainly through faceto-face semi-structured interviews. Interviewees at the universities included the Dean or representative, the Teaching Practice (practicum) coordinator and two Teaching Practice supervisors; at the schools the interviewees were the principal or representative, the Teaching Practice coordinator and two mentor teachers at the schools. Senior members of national and provincial departments of education were also interviewed. Cross-cutting trends and issues were identified through content analysis of the interviews. Documentary analysis was done of relevant policy and legal frameworks.

\section{Findings of the research}

It was evident from all the interviews that a strong commitment to building quality education exists across the country. The significance and value of initial teacher education was shared by all who were interviewed, although there was some divergence in how people understood the particular role of schools in teacher education. The majority of interviewees saw placements as providing exposure to the daily work of teachers ('student teachers are exposed to school structure and organisation, expectations, reality, experience, diversity issues'...'examinations, professional development and staffroom politics'/ 'students are able to translate the theoretical knowledge gained at the university into effective teaching practice') while some others referred to the opportunity for development and growth ('it helps to develop student confidence and teacher identity'/ 'students could engage in selfdiscovery under the guidance of the mentors').

Many initiatives to build good school-university relationships were apparent at the level of individual institutions. These included mentor education, rural placements, community-university collaborations, subject committees, leadership training, and various school improvement programmes. As part of the curriculum development taking place around the new national policy on teacher education qualifications, vibrant discussion on the purpose of Teaching Practice was also apparent at some universities. Such discussions included how to 'improve the relationship between academics and the school' and how to encourage the university to become 'actively involved in mentoring, capacity development among teachers, student support and community interaction'.

It was, however, very obvious that insufficient communication exists across the different sectors on roles, responsibilities and expectations with regard to supporting student teachers during the practicum. This dearth of communication was at times at 
a basic organisational level, for example about the timing of school placements, the number of lessons to be taught by student teachers, the role of the mentor teacher, etc. Schools spoke about issues like 'the absence of lecturer supervision', 'a lack of clarity regarding norms and standards or terms of reference', 'the absence of a forum to encourage a closer relationship', 'universities seem to expect the schools to do far more than they can manage' and 'no-one seemed to know who should contact whom'. Where communication did exist, it tended to be procedural, with almost no evidence of deeper dialogues, or what Edwards and Mutton $(2007,509)$ call 'expanding mutual understanding of shared tasks and problems; and the development of expertise in negotiating meanings and the response to those meanings'.

The historical context of schooling in South Africa played a major role in how people saw the potential for schools to be active partners in teacher education. Political and social sensitivities were high, with strong arguments that the history of inequality and exploitation should not define which schools are seen as suitable for initial teacher education placements. The argument was put that, rather than favouring well-resourced schools, qualities such as 'organization, resilience, discipline and practice' should determine the identification of schools for Teaching Practice. A strong message emerging from the research was that the identification of certain schools as Professional Practice schools should not create racial or social divisions and hierarchies within the system. Many schools, it was argued, are working hard under difficult conditions, and quality might manifest in different ways in different situations. Some indicators of quality, like good academic results, might be more obvious to the public, but student teachers also have much to learn from schools that, for example, support learners in difficult conditions, or have strong links with their communities.

It was clear that the material conditions of schools and universities offered significant challenges to supporting or sustaining effective school-university partnerships. At university level, resources are in general insufficient to cover the costs of Teaching Practice, particularly for student and lecturer transport, student accommodation, employment of additional supervisors, etc. This has led in many cases to a cut-back on supervisory visits to the school, creating the perception of universities not caring about their student teachers. The large number of student teachers relative to the number of university staff in faculties of education also often meant that school visits were outsourced to external contract staff, thus diminishing the potential to build curricular links between the school and the university. Incentives for university academics were described in almost all cases as being linked to research outputs, with time to build relations with schools being the invisible, takenfor-granted work of - often more junior - academics, a phenomenon that has been referred to as the proletarianisation of teacher educators within higher education (Ellis, McNicholl, Blake \& McNally 2014).

For schools, there was the fundamental challenge of time and space for teachers to mentor the student teachers. It became apparent during this research that heavy 
teaching loads, full school curricula and high stakes assessment regimes often led to teacher support to student teachers occurring in a rushed fashion, either during breaks or in a few moments after the lesson. The overcrowding and limited space at some schools meant that there was no physical space for student teachers (or teachers) to have a quiet space for reflection and planning.

Analysis of legislation and policy revealed that teacher involvement in teacher education is not dealt with specifically or explicitly at national, provincial or institutional level, and that one has to 'read between the lines' to understand the implications of current legislation and policies. Policies that might support teacher involvement in teacher education, like career paths for mentor teachers, are in their infancy.

\section{Analysis of the findings}

Two theoretical lenses are used here to discuss the findings: cultural historical activity theory (CHAT) and Fraser's (2008) three-dimensional notion of social justice.

CHAT offers a lens through which to understand the collaborations and spaces that need to be traversed when working across different systems (e.g. the school and the university). Through understanding such spaces, one is able to explore the tensions, contradictions and possibilities of crossing institutional boundaries, as one seeks to bring together different sources of expertise in the different activity systems (Ellis, Edwards \& Smagorinksy 2010; Zeichner et al. 2015).

The activity system associated with CHAT generally includes six categories of analysis: subject, object, outcome, instruments/ tools, rules, community and division of labour. This is represented in the figure below:

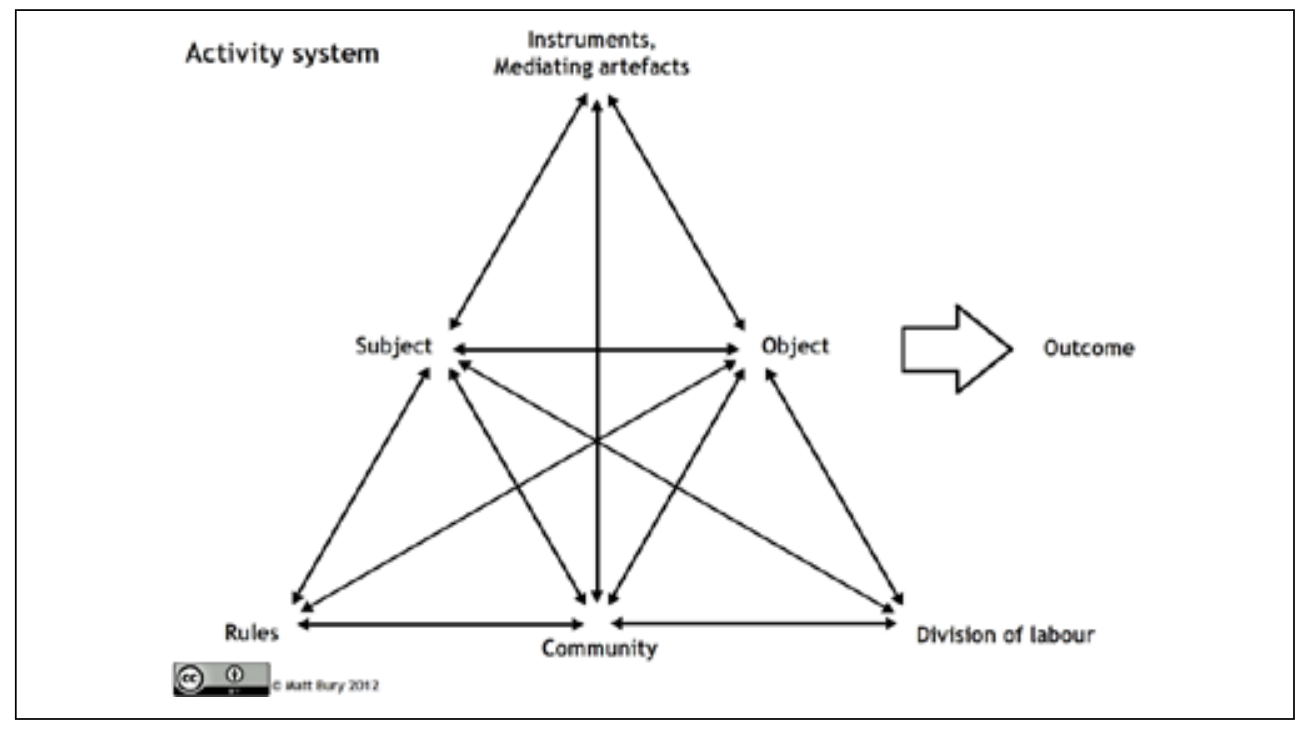


Although each of the categories within CHAT provides its own useful insights, the discussion here focuses on four categories that featured most predominantly in the data, namely object, outcome, instruments, and division of labour. For each of these categories, opportunities and threats are identified, in order to identify those features that both inhibit and provide possibilities for action.

The research showed that there was an active and shared commitment to quality education in the country by all participants in the research (object). There was a strong recognition that, twenty years into democracy, there was still much work to be done to create a fully functional education system that would empower young learners both academically and socially. There were also overlaps in the purposes and expectations for school involvement in teacher education (outcome), with both schools and universities emphasising knowledge sharing, practical experience, and interaction with experienced teacher mentors. The similarity in the intended outcome, however, was very general; further research might reveal differences in how schools and universities understood the specific purpose of practical experience.

The tools or instruments associated with the school-university relationship, however, constitute a significant impediment to meaningful collaboration. As previously explained, teacher education curriculum policy defines broad principles of different types of learning (disciplinary, pedagogical, practical, fundamental and situational learning) and a set of eleven basic competences of a beginner teacher (DHET 2015b). Teachers, on the other hand are, since 2012, working within a national curriculum, the Curriculum and Assessment Policy Statements (CAPS), which is based on specification of content and detailed teaching schedules. The school curriculum thus offers little room for differentiation, very tight sequencing and pacing, and an emphasis on standardised tests. Within such a life-world, it is not surprising that teachers would hesitate to take on the intended outcomes of the 'freer' teacher educator, that their material interests would lead them to discourage student teachers from classroom innovation, or that they would resist being engaged in classroom support that might disrupt the flow of their work.

Despite the general feeling that student teachers should be placed at schools in different contexts, inadequate infrastructure and capacity at many schools can also be considered a constraining tool or instrument. A shortage of facilities like libraries, laboratories, books or desks undermines student teachers' (and teachers') abilities to function in optimal ways, as does a disorganised internal management system that lacks clear systems and procedures.

Policy on teacher education expects that student teachers are formally assessed during their time in schools. However, the tools associated with the assessment of student teaching practice will need to be much more thoroughly discussed than is currently the case if there is to be coherence of purpose in a school-university partnership arrangement. This research showed that communication across schools and universities about the goals and arrangements for Teaching Practice was very 
weak, with assessment instruments sometimes varying from different subject lecturers within the same university.

The final category from CHAT that emerged strongly from the research was that of division of labour, with both school and university human resource arrangements constraining the building and sustaining of school-university partnerships. University funding mechanisms in South Africa heavily favour postgraduate and research outputs over community interaction or relationship building. This places a substantial burden on teacher educators who, as in other parts of the world, occupy a hybrid space between the pressure for research productivity and the time needed to build professional relationships with schools (Ellis, McNicholl \& Pendry 2012). School-based policy has been grappling for years to implement a professional career pathway for teachers, rather than the current situation where a move into management is the sole form of upwards mobility. In the absence of a supportive mechanism for the work of mentoring and supervision of student teachers, the exercise is likely to remain dependent on goodwill (which fortunately seems to be in abundance) for the foreseeable future.

McNicholl and Blake (2013) have argued that activity theory is often limited to interpreting specific, local practices and that the macro sociopolitical structures tend to be understated in activity system analysis. Interestingly, this research seemed to bear this out, with certain very strong categories from the data falling outside of the activity theory framework. These categories were fundamentally social in nature, and included safety, language and location, all of which are closely linked to the historical and political situation of the country. University supervisors spoke of the difficult decision as to whether to place student teachers at schools in crime-ridden areas, or where teaching and learning was not optimal, or where schools were not functional, thereby hindering the intention to work with schools in all social contexts. Teachers spoke about student teachers who were not conversant in the language of the learners, as they were from a different province, as well as the poor infrastructure and facilities of many schools located in rural areas. For schools in poorer and rural areas in particular, there was a concern that student teachers lacked awareness of the learners' social backgrounds and were therefore unable to engage with them in an appropriate manner.

The research concluded by offering four recommendations, namely:

- All schools should be viewed as having the potential to be good sites for the school-based component of initial teacher education, and thus as potential Professional Practice schools.

- Minimum conditions should be present in all schools where student teachers are placed for Teaching Practice.

- Better communication is needed between schools and universities about the goals and activities of initial teacher education. 
- Policies and strategies should be directed at improving the capacity of schools and universities to work together more optimally to enhance the quality of teacher education.

\section{A CONTRIBUTION TO SOCIAL JUSTICE}

At first glance, the above recommendations could be viewed as a straightforward call for basic functionality and coherence in the system of teacher education. How then might one interpret these recommendations within a broader framework of advancing social justice, so fundamental to building an equitable education system in South Africa?

At the very least, the activity settings identified through the research can provide categories for schools and universities to engage in dialogue and negotiation about modes of acting and doing, thus as a 'way in' to new forms of engagement. From this perspective, contradictions can be seen as sources of change and innovation, and 'it is in the process of resolving contradictions that activity systems are transformed and expansive learning takes place' (Edwards, Tsui \& Stimpson 2009, 17).

From a perspective of social justice, however, a systemic attempt at building school-university partnerships for quality teacher education must go beyond creating opportunities for dialogue. Material conditions and institutional arrangements provide the environment within which different affordances of practice are possible. As Childs, Edwards \& McNicholl (2013) have pointed out, student teachers' workplace learning can be analysed across different planes - society, institution, activity setting, and person - and societal needs and conditions need to be conducive to the values, motives and objectives of the activity setting.

The challenge, then, becomes to identify the leverage areas and institutional arrangements that offer the most sustainable 'affordances of practice' in the South African context, and to link these arrangements to the advancement of social justice in teacher education. The notion of scales of justice helps locate the findings of the research within the desired outcome of social justice across the system as a whole.

Fraser's (2008) three-dimensional theory of justice helps us to 'measure' the recommendations of the research against the aspiration of social justice. Fraser distinguishes between the economic, cultural and political dimensions of social justice, namely redistribution (the what), recognition (the who) and representation (the how).

By linking the recommendations of the research to Fraser's notions of social justice, one is able to infer the potential of these recommendations to go beyond technical coherence to advancing deeper levels of social transformation. To explain:

The recommendation that all schools should be viewed as having the potential to be good sites for the school-based component of initial teacher education, and thus as potential Professional Practice schools, recognises the necessary knowledge 
contribution of all the partners in teacher education, whatever their social location. The recommendation acknowledges the politics of inequality and specifically cautions against only working with those schools that have benefitted from better historical conditions, arguing that many schools in poor and rural areas provide important insights into issues like community-school linkages. This democratic epistemology (Zeichner et al. 2015) offers opportunities for student teachers (as well as university lectures) to learn important lessons like resilience and agency, something that they might not learn in better-resourced contexts.

The second recommendation - that minimum conditions should be present in all schools where student teachers are placed for Teaching Practice - is clearly an argument for the redistribution of resources and capacity that are at present so unequally distributed across the system. The recommendation derives from the acknowledgement that not all schools offer worthwhile learning environments for student teachers and that certain criteria do need to be in place for schools to be selected as Teaching Practice sites. The research recommends a set of criteria to which all schools could and should aspire if they are to meet the expectations of a sound learning environment, including leadership and vision, professionalism, functionality, good teaching and learning, resilience, and a commitment to learner, teacher and student teacher growth.

The third recommendation - that better communication is needed between schools and universities about the goals and activities of initial teacher education - is on the one hand just about basic efficiency. However, taking this further, one can also locate communication as an example of representation, where different stakeholders participate in the educative process, trust is built and academic and practitioner knowledge is connected. Zeichner $(2014,264)$ argues for the importance of 'unpacking and analysing the underlying commitments to particular purposes of public schooling and the meaning of teaching, learning, the teacher's role and the process of learning to teach'. This highlights the importance of not seeing PPSs as 'neutral' or 'ideology-free' sites of activity, but as sites for different parties involved in teacher education to come together for deep debate about the goals and practices of education in South Africa.

The final recommendation - that Professional Practice schools cannot be separated from policies and strategies directed at improving the general capacity of schools and universities - seems to include all three dimensions of social justice, i.e. the redistribution of resources and opportunities, the recognition of educators in the process of mutual learning, and the representation of teacher agency in improving the system of education.

Many of these policies and strategies are already underway in South Africa, although they are at variable stages of implementation or success. Professional development opportunities that exist include leadership training for school principals, curriculum leadership and management training for heads of department, 
professional learning communities at schools, and mentor programmes to promote teacher learning and student teacher support.

Operational initiatives include a system of continuing professional development, norms and standards for school infrastructure and political and social interventions to improve levels of safety and security in communities. Still missing, though, is better state funding of Teaching Practice, and school staffing norms that allow time and space for substantial dialogue to happen between teachers, university lecturers and student teachers.

\section{TOWARDS A SYSTEM-WIDE INTERVENTION}

Much has been written about the complexity of democratic interventions at local level, even in more resource-rich environments (Klein et al. 2013; Zeichner et al. 2015). How much more complex, then, is the challenge to sustain interventions for social justice across a national teacher education system in a country like South Africa, that is struggling to overcome a historical legacy of gross inequality? The investigation of this one policy proposal has shown the interconnectedness of various levels of a system; the challenge is to identify those affordances that have the most leverage within an environment of constrained capacity.

Participants in this research certainly seemed to have a shared vision concerning the contribution of teacher education to building a just education system for all. However this is a generalised aspiration that says little about the form that such an education system would take, and it is here that different discourses can emerge. In recent years the school curriculum has narrowed and become more prescriptive, and - at the same time as there is a drive to encourage teacher professional learning communities - there has been increased attention to testing and bureaucratic accountability in schooling. How teacher education responds to these dual imperatives remains to be seen.

Ellis $(2010,112)$ has argued for school-university partnerships to 'recognize and plan for the agency of beginning teachers, in engaging with the social systems within which they are working' so that teacher education becomes a way of 'using experience as a means to develop an idealised vision of the future' $(2010,117)$. The agency of student teachers to imagine a better future is a powerful entry point into building a new vision of education; however agency must be supported by institutional conditions that encourage and motivate, or it will lead to disillusionment and teacher burnout.

The complexity and interconnectedness of the challenges in education in South Africa call for boundary crossing, or recognition of the complementary nature of each activity system, as different sectors offer their various forms of expertise. This research pointed to the lack of communication that exists between universities and schools; without better communication, trust will not be built and it will be difficult to 
understand and value the contribution of each element of the system. Edwards (2011) calls this 'relational agency', a capacity to work with others to strengthen purposeful responses to complex problems. Samuel's (2014) research on the changing nature of 'teacher voice' in South Africa also concludes with a call for multiple partners to unite in their quest to improve the quality of teaching and learning in the country.

Material conditions and institutional capacity are central to enable the affordances or potentialities of the different activity systems. This research identified some of the resources required to enhance teacher education and these remain central. Universities, schools, and communities in South Africa all operate under constrained conditions. Despite this, schools were optimistic that they could offer quality education to student teachers, and spoke proudly of their drive to excel, attempts to 'improvise and be creative' and teachers 'who make the most of what they have'. Such an attitude certainly illustrates high levels of agency; the dilemma of sustainability does, however, remain. An enabling policy environment, that recognises and values teacher education, will need to go hand in hand with more practical enablers at different levels of implementation, including terms of reference, funding, training, curriculum, etc.

\section{CONCLUSION}

This paper has outlined an example of one proposed systemic intervention in teacher education in South Africa and has discussed the potential it embodies for advancing social justice. The complexity that the research has outlined is probably not the answer that policy-makers, who are responsible for designing new systems, want to hear. Nevertheless, lessons from the international literature are a reminder that policy needs to be realistic about what it takes for schools and universities to be able to work together in mutually beneficial ways. Ambitious expectations and plans will not take root without extensive human and financial capacity and resources, all of which is in short supply in South Africa.

In its focus on systems, it is important to note that the paper has not dealt with the crucial area of curriculum and pedagogy in teacher education. Following the argument that the system should focus on creating institutional conditions for professional agency to flourish, one might argue that it is in fact in the realm of curriculum and pedagogy that the most potential opportunities for social justice interventions reside.

Teacher education is a 'hybrid space' that crosses institutional boundaries. As such, it offers a potentially powerful location for teachers, student teachers and university lecturers to bring their different resources together, to discuss the 'how', the 'why' and the 'where to' (Edwards 2011) of education. By inserting such discussions into the curriculum and pedagogy of teacher education, spaces can open for theoretical and practical deliberation on what good teachers should be and do in 
a South African context. If as professionals we can collectively answer that question, we will have come a long way to addressing the challenge of social justice.

\section{ACKNOWLEDGEMENTS}

This research was funded by the Department of Higher Education and Training as part of a grant from the European Union. Data was collected by a team that consisted of Peter Beets, Moira Bladergroen, Marie Louise Botha, Rika Joubert, Chiwimbiso Kwenda, Chris Reddy, Maureen Robinson, Linda Rutgers, Melanie Sadeck and Kristina Solum.

\section{REFERENCES}

Broadbent, C. and J. Brady. 2013. Leading change in teacher education in Australia through university-school partnerships. The European Journal of Social and Behavioural Sciences (eISSN: 2301-2218): 687-703.

Browne, L. and J. Reid. 2012. Changing localities for teacher training: The potential impact on professional formation and the university sector response. Journal of Education for Teaching: International Research and Pedagogy 38(4): 497-508.

Childs, A., A. Edwards and J. McNicholl. 2013. Developing a multi-layered system of distributed expertise: What does cultural historical theory bring to understandings of workplace learning in school university partnerships? In Workplace learning in teacher education: International practice and policy. Edited by O. McNamara, J. Murray and M. Jones, 29-45. New York: Springer.

Darling-Hammond, L. 2014. Strengthening clinical preparation: The holy grail of teacher education. Peabody Journal of Education 89(4): 547-561.

Departments of Basic Education and Higher Education and Training. 2011. Integrated Strategic Planning Framework for Teacher Education and Development in South Africa, 2011- 2015. DBE/ DHET: Pretoria.

Department of Higher Education and Training. 2015a. Relationships between teacher supply and demand and the size, shape and substance of teacher education in South Africa. Internal report.

Department of Higher Education and Training. 2015b. Revised Policy on the Minimum Requirements for Teacher Education Qualifications. Government Gazette, Vol 596, No 38487, 19 February 2015. Pretoria: Government Printers.

Edwards, A. 2011. Building common knowledge at the boundaries between professional practices: Relational agency and relational expertise in systems of distributed expertise. International Journal of Educational Research 50(1): 33-39.

Edwards, A. and T. Mutton. 2007. Looking forward: Rethinking professional learning through partnership arrangements in initial teacher education. Oxford Review of Education 33(4): 503-519. 
Edwards, G., A. Tsui and P. Stimpson. 2009. Contexts for learning in school-university partnerships. In Learning in school-university partnership: Sociocultural perspectives. Edited by A. Tsui, G. Edwards and F. Lopez-Real. London: Routledge.

Ellis, V. 2010. Impoverishing experience: The problem of teacher education in England. Journal of Education for Teaching: International Research and Pedagogy 36(1): 105-120.

Ellis, V., A. Edwards and P. Smagorinsky, eds. 2010. Cultural historical perspectives on teacher education and development: Learning teaching. London and New York: Routledge.

Ellis, V., J. McNicholl and A. Pendry. 2012. Institutional conceptualisations of teacher education as academic work in England. Teaching and Teacher Education 28(5): 685-693.

Ellis, V., J. McNicholl, A. Blake and J. McNally. 2014. Academic work and proletarianisation: A study of higher education-based teacher educators. Teaching and Teacher Education 40(4): $33-43$.

Fraser, N. 2008. Scales of justice: Reimagining political space in a globalizing world. Cambridge: Polity Press.

Gravett, S., N. Petersen and G. Petker. 2014. Integrating foundation phase teacher education with a 'teaching school' at the University of Johannesburg. Education as Change 18(1): 107-119.

Gravett, S. and S. Ramsaroop. 2015. Bridging theory and practice in teacher education: Teaching schools - a bridge too far? Perspectives in Education 33(1): 131-146.

Henning, E., G. Petker and N. Petersen. 2015. University-affiliated schools as sites for research learning in pre-service teacher education. South African Journal of Education 35(1): 108112

Klein, E., M. Taylor, C. Onore, K. Strom and L. Abrams. 2013. Finding a third space in teacher education: Creating an urban teacher residency. Teaching Education 24(1): 27-57.

Mattson, M., T. Vidar Eilertsen and D. Rorrison, eds. 2011. A practicum turn in teacher education. Rotterdam: Sense Publishers.

McNicholl, J. and A. Blake. 2013. Transforming teacher education: An activity theory analysis. Journal of Education for Teaching: International Research and Pedagogy 39(3): 281-300.

Robinson, M. 2015. Teaching and learning together: The establishment of Professional Practice schools in South Africa. A research report for the Department of Higher Education and Training. Stellenbosch University.

Samuel, M. 2014. South African teacher voices: Recurring resistances and reconstructions for teacher education and development. Journal of Education for Teaching: International Research and Pedagogy 40(5): 610-621.

Sayed, Y., A. Kanjee and M. Nkomo, eds. 2013. The search for quality education in post-apartheid South Africa: Interventions to improve teaching and learning. Cape Town: HSRC Press.

Zeichner, K. 2014. The politics of learning to teach from experience. In Learning teaching from experience: Multiple perspectives and international contexts. Edited by V. Ellis and J. Orchard. London, New York: Bloomsbury Academic.

Zeichner, K., K.A. Payne and K. Brayko. 2015. Democratizing teacher education. Journal of Teacher Education 66(2): 122-135. 